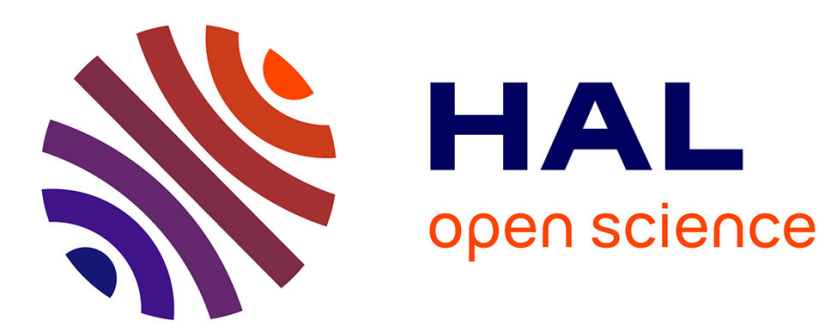

\title{
Insight into muscle physiology through understanding mechanisms of muscle pathology
}

Olivier Cazorla, Stefan Matecki

\section{To cite this version:}

Olivier Cazorla, Stefan Matecki. Insight into muscle physiology through understanding mechanisms of muscle pathology. Journal of Muscle Research and Cell Motility, 2017, 38 (1), 10.1007/s10974-0179479-3 . hal-01757631

\section{HAL Id: hal-01757631 \\ https://hal.umontpellier.fr/hal-01757631}

Submitted on 16 Dec 2019

HAL is a multi-disciplinary open access archive for the deposit and dissemination of scientific research documents, whether they are published or not. The documents may come from teaching and research institutions in France or abroad, or from public or private research centers.
L'archive ouverte pluridisciplinaire HAL, est destinée au dépôt et à la diffusion de documents scientifiques de niveau recherche, publiés ou non, émanant des établissements d'enseignement et de recherche français ou étrangers, des laboratoires publics ou privés. 


\title{
Insight into muscle physiology through understanding mechanisms of muscle pathology
}

\author{
Olivier Cazorla $^{1} \cdot$ Stefan Matecki $^{1}$
}

Keywords Muscle $\cdot$ Force $\cdot$ Signaling $\cdot$ Regeneration .

Myopathy

The main theme of the 45th EMC was Muscle Research in Health and Disease. It was the intention of the organizers to cover a wide range of topics focusing on muscle development and function, both in physiology and pathology. The program included the following sessions: "Molecular motor and contractile function", "Mitochondrial dynamics", "Muscle cytoskeleton", "Muscle plasticity and chronic disease", "Neuro-muscular disease and therapeutic approach", "Excitation-contraction coupling in cardiac muscle", "Muscle development and aging", Skeletal muscle diseases", "Heart and heart failure", "Smooth muscle and vascular function", "Epigenetics of muscle regeneration", "Molecular motor and contractile structure", "Mechanotransduction", "Excitation-contraction coupling in skeletal muscle", "Bio energetics and ROS" and "Cardiomyopathy and Heart failure". The sessions were chaired by leading international and French scientists in those fields, and who introduced the sessions.

The Young Scientist Session preceded the Conference opening ceremony. It was organized in the first teaching class of anatomy created at Montpellier University in 1220 , that was very attractive at this time, to students from all over Europe due to the incorporation of the knowledge of Arabic and Jewish humanists. Notably, Nostradamus and François

Olivier Cazorla

olivier.cazorla@inserm.fr

1 INSERM U1046, CNRS UMR9214, University of Montpellier, Montpellier, France two parts: (i) How to design a research proposal/protocol presented by Luc Bertrand (Belgium) and How to choose the good statistics by Denis Angoulvant (France) and (ii) How to write a scientific manuscript by Mathias Gautel (England) and scientific integrity against the pressure to publish by Pieter De Tombe (USA).

The opening lecture was held by Professor Andrew Marks from Columbia University, New York, who presented his contribution to research on the Ryanodine receptor: structure, function and therapeutic targeting for diseases of heart and muscle.

It was a great pleasure for us to host over 334 scientists from all over the world. There were 30 lectures delivered by the invited speakers who were the top researchers in their fields, 56 short oral talks presented mainly by young researchers and 190 poster presentations. The scientific quality of young researchers' poster presentations were evaluated by the chairpersons of each session. The committee granted 11 young researchers with a prize for best poster presentations among the 75 participants. The awards were co-sponsored by the EMC organizers and the Journal of Muscle Research and Cell Motility published by Springer. Awards for best poster presentation went to: Simona Feno from Italy, Felipe De Souza Leite from Canada, Christopher Johnson from the USA, Florian Dilasser from France, Robbert Van Der Pijl from the Netherlands, Maryna Panamarova from England, Laura Salavadori from Italy, Haikel Dridi from France, Heather Best from Australia, Nourdine Chakouri from France, and Colline Sanchez from France.

Speakers and chairmen of the EMC scientific sessions contributed to this Special Issue by submitting their papers. We are grateful to all of them for their efforts.

This issue consists of three reviews and two original papers, covering the topics of the Conference with an emphasis on translational studies, along with abstracts of 
the EMC short talks and poster presentations from the 45th European Muscle Conference, which was held in Montpellier (France) in September 2016.

The main topic presented in this series was focused on several cellular mechanism implicated in muscular remodeling, such as epigenetic or calcium homeostasis regulation.

Barreiro and Tajbakhsh (Barreiro and Tajbakhsh 2017) provided a summary of the contents discussed in session 08 , titled "Epigenetics of muscle regeneration". In eukaryotic cells, chromatin appears in several forms and is composed of genomic DNA, protein and RNA. The protein content of chromatin is composed primarily of core histones that are packaged into nucleosomes, resulting in the condensation of the DNA. Several epigenetic mechanisms regulate the stability of the nucleosomes and the protein-protein interactions that modify the transcriptional activity of the DNA. The main theme of that session was to highlight the most recent progress on the role of epigenetics in the regulation of muscle development and regeneration.

Gueffier and colleagues (Gueffier et al. 2017) provide evidences of the implication of the non-selective cationic channel TRPM4 in the physiological cardiac hypertrophy during exercise training. Indeed, TRPM4 prevents the activation of the calcineurin-NFAT pathway through a negative effect on calcium entry, favoring the activation of PI3-K/Akt pathway.

The review by Santulli and co-workers (Santulli et al. 2017) covers the role of calcium $(\mathrm{Ca} 2+)$ release from intracellular stores in the regulation of skeletal muscle contraction. The type 1 ryanodine receptors (RyR 1 ) is the major $\mathrm{Ca}^{2+}$ release channel on the sarcoplasmic reticulum (SR) of myocytes in skeletal muscle and is required for excitation-contraction (E-C) coupling. This review article explores the role of RyR 1 in the skeletal muscle physiology and pathophysiological remodeling.

Matecki and colleagues (Matecki et al. 2017) examined the implication of the sarcoplasmic reticulum (SR) calcium release channel/ryanodine receptors (RyR1) in role in the diaphragm muscle functional remodeling following muscle unloaded using a pig model of ventilator-induced diaphragmatic dysfunction.

Finally, in connection to human health, Roy and Le Guennec (Roy and Le Guennec 2016) present a review article on the impact of omega-3 poly-unsaturated fatty acids ( $\omega 3$ PUFAs) on cardiac function. Their review examines recent literature regarding health aspects of $\omega 3$ PUFAs intake from fish or supplements, and discusses different arguments and reasons supporting these conflicting findings. They suggest limiting the conflicting findings, a standardization of the methodology and surrogate outcomes (dose, type of fatty acids, and rate of oxidation).
Acknowledgements We are grateful to the participants and the speakers who accepted our invitation to contribute with their work to create an excellent platform to discuss the latest achievements in muscle research and to initiate new collaborations. We are grateful to the contributors of the meeting Université de Montpellier, Région Languedoc-Roussillon, AFM-Téléthon, Pôle Biosanté Rabelais, Montpellier Méditerranée Métropole, RyR-I foundation

\section{References}

Barreiro E, Tajbakhsh S (2017) Epigenetic regulation of muscle development. J Muscle Res Cell Motil. doi:10.1007/s10974-017-9469-5

Gueffier M et al (2017) The TRPM4 channel is functionally important for the beneficial cardiac remodeling induced by endurance training. J Muscle Res Cell Motil. doi:10.1007/s10974-017-9466-8

Matecki S, Jung B, Saint N, Scheuermann V, Jaber S, Lacampagne A (2017) Respiratory muscle contractile inactivity induced by mechanical ventilation in piglets leads to leaky ryanodine receptors and diaphragm weakness. J Muscle Res Cell Motil. doi:10.1007/s10974-017-9464-X

Roy J, Le Guennec JY (2016) Cardioprotective effects of omega 3 fatty acids: origin of the variability. J Muscle Res Cell Motil. doi:10.1007/s10974-016-9459-z

Santulli G, Lewis D, Marks AR (2017) Physiology and pathophysiology of excitation-contraction coupling in skeletal muscle: the functional role of ryanodine receptor. J Muscle Res Cell Motil. doi:10.1007/s10974-017-9470-z 